\title{
KOMUNIKACIJA
}

\section{POLITIKỤ IR ŽINIASKLAIDOS \\ SĄVEIKOS: CINIZMAS KAIP POLITINĖS KOMUNIKACIJOS STILIUS}

Doc. DR. Renata MatKevičIEnĖ

Vilniaus universiteto Komunikacijos fakultetas

Vilnius University Faculty of Communication

Sauletekio al. 9, LT-10222 Vilnius

El.paštas renata.matkeviciene@kf.vu.lt

\section{Santrauka}

Temos pasirinkima paskatino pastaruoju metu tiek visuomeneje, tiek žiniasklaidoje ryškẻjanti kritiško politiniu procesu vertinimo tendencija: analizuojant politinius procesus, vertinant valdžios ar politiku veiksmus, ypač politiniu rinkimu kampanijas, pastebimas negatyvus, kritinis požiūris, reiškiamas tiek žiniasklaidos atstovu, politologų, visuomenès veikejju, tiek ir pačiu politikų.

Negatyvumas pastebimas ir pačiu politiku tarpusavio komunikacijos diskurse: apie konkurentus, ar tiksliau apie oponentus, ju kalbas, keliamas problemas dažnai atsiliepiama itin kritiškai, išsakant tik neigiama nuomone, nurodant tik neigiamus argumentus ar kritines pastabas. Žinoma, toks negatyvus politikos konstravimas daugiausia perimamas iš žiniasklaidos, nes retas kuris pilietis pats aktyviai dalyvauja politiniuose procesuose ir mato politiku tarpusavio bendravima, netarpininkaujama žiniasklaidos. Nors tai ir nera tikroji realybe, o tik žiniasklaidos formuojamas politikos atspindys, tačiau dažniausiai remiantis būtent žiniasklaidos konstruojamu turiniu ir yra formuojama ir suformuojama visuomenes nuomoné apie politika, politikus, politi- 
kos institucijas ir ju veiklą. Verta atkreipti demesį ir ị tai, kad žiniasklaida ne visuomet būna itin objektyvi realybès formuotoja. Turédama savu interesų, žiniasklaida yra tendencinga, šališka politikos lauko atspindžio konstruotoja, tačiau akivaizdu ir tai, kad pati viena be politiku dalyvavimo ji negalètu parengti politinio turinio, todèl ta politine komunikacija, kuria pateikia žiniasklaida, yra politikų ir žiniasklaidos bendradarbiavimo ar (ne)su(si)tarimo rezultatas, iš dalies atspindintis politinius procesus ir, tikètina, politinès komunikacijos pobūdį.

Šiame straipsnyje bus analizuojamas cinizmas kaip politinès komunikacijos stilius ir jo raiškos žiniasklaidoje tiriant žiniasklaidoje pateikiamu politiku kalbų turini.

Straipsnyje pateikiama Delfi.lt skilties „Politiku akimis“ keleto metu straipsniu turinio kokybinè analizè ryškinant politinio cinizmo elementus.

Reikšminiai žodžiai: politikai; žiniasklaida; politinè komunikacija; cinizmas; kritiškumas; negatyvumas, politinès komunikacijos stilius.

\section{Ivadas}

Politinès komunikacijos tendencijos: ar cinizmas yra vyraujantis politinès komunikacijos stilius

Cinizmas ir jo raiška politinejje komunikacijoje nèra nauja, nors Lietuvoje beveik nenagrinejjama tema. Esminis užsienio tyrèjų, analizuojančių šią problematiką, klausimas - kas lemia cinizmą, pasireiškianti politikų kalbose, dominuojanti žiniasklaidos pateikiamuose politinių procesų vertinimuose ar piliečių kritiškuose svarstymuose? O gal tiksliau - kiek cinizmo pasireiškimas politinèje komunikacijoje yra susijęs su pasitikejjimu ar nepasitikejjimu politikos institucijomis ir apskritai valdžia?

Daugelio politinį cinizmą ir kritiškumą nagrinejjusių mokslininkų darbuose yra ryškinamas žiniasklaidos vaidmuo: siekdami suin- 
triguoti ir paprastai, bet įdomiai pristatyti politinès srities naujienas, žiniasklaidos atstovai pasitelkia kritiką, dažnai cinizmą. Sekdami žiniasklaidoje dominuojančiomis lengvo turinio naujienomis, kritišku ir daugiau negatyviu nei objektyviu situacijos ar tam tikrų veiksmų vertinimu, politikai, perimdami žiniasklaidoje dominuojantị toną, atitinkamai konstruoja ir savo politinị komunikacijos stilių: trokšdami žiniasklaidos dėmesio, populiarumo, politikai svarbias problemas taip pat siekia pristatyti įdomiai, supaprastindami pagrindini pranešimą, sumenkindami keliamas ir sprendžiamas problemas ar kritiškai ịvertindami oponentų veiksmus ar kalbas. Kaip teigia Dickas Pelsas (2003, p. 47), „politinès komunikacijos stilius ir pasitikejjimas daugiausia kuriamas bendru politikų ir juos delegavusių piliečių sutarimu, kurị lemia politinis stilius ir skonis“. Pastaraisiais metais mokslininkų darbuose nurodomos kelios šiuolaikinès politinès komunikacijos specifiką lèmusios priežastys, tokios kaip: įsigalejjusi politinè reklama, politiniai ryšiai su visuomene ir politikų vartojama populistinė retorika politiniuose debatuose (Van Dalen, Albæk, de Vreese, 2011). Ypač pastarosios ịsigalejimas politinèje komunikacijoje yra siejamas su menkstančiu pasitikejjimu politikais ir politikos institucijomis (mažejimas pastebimas ne tik Lietuvoje, bet ir visoje Europoje (Adriaansen, van Praag, de Vreese, 2010; Levi, Stoker, 2000, p. 482). Pasitikejjimas politikais yra kompleksinis dalykas ir jis nulemtas ne tik politinès komunikacijos, bet ir pačių politikų veiklos, jos skaidrumo ar neskaidrumo, korupcijos skandalų, taip pat ir žiniasklaidos, konstruojančios politikos matomumą visuomenèje. Kaip pabrèžia mokslininkai, žiniasklaidos ir politikų kuriamas politinis diskursas, ypač per politinių rinkimų kampaniją, išryškinant politinio proceso trūkumus, sukuriant ar akcentuojant politikų tarpusavio kovą, dažnai tampa priemone, atgrasančia piliečius dalyvauti rinkimuose, formuojančia neigiamą, cinišką požiūrị ir didinančia atsitraukimą nuo dalyvavimo politiniuose procesuose (Guggenheim, Kwak, Campbell, 2011; Elenbaas, de Vreese, 2008, p. 550). 
Kritiškumas, negatyvumas ar cinizmas: kuris terminas atspindi politinëje komunikacijoje vyraujančias tendencijas

Dalyvaudami, stebèdami ir vertindami politinius procesus ir politinę komunikaciją susiduriame su kritišku, kartais pašaipiu, negatyviu politinių procesų, veikejų ir jų veiksmų vertinimu. Koks terminas tinkamai apibūdintų tokị komunikacijos toną ar stilių: kritiškumas, negatyvus vertinimas ar cinizmas?

Politinès komunikacijos tyrimuose, nagrinëjančiuose sumažèjusị visuomenès pasitikèjimą politikais ir politikos institucijomis, akcentuojamas politinis cinizmas - ir kaip priežastis, ir kaip pasekmè politikų bei žiniasklaidos komunikacijos (perduodamų pranešimų apie politinius procesus) tono (Guggenheim, Kwak, Campbell, 2011). Politinio cinizmo apibrèžties analizè politinès komunikacijos srities tyrimuose išryškina šio termino sudetingumą, sąsajas su kitais terminais, pabrèžiančiais nepasitikèjimą, neigimą ar neigiamą vertinimą.

Tokie terminai kaip negatyvumas, kritiškumas, skepticizmas, cinizmas būtent dèl jau paties termino suponuojamo neigiamo tam tikro reiškinio vertinimo, neigimo ir nepasitikejjimo kuo nors skatinimo politinès komunikacijos mokslininkų vartojami kaip termino „politinis cinizmas" sinonimai. Remdamiesi įvairiais žodžių reikšmes aiškinančiais žodynais ${ }^{1}$, pateiksime populiarias šiu terminų reikšmes:

- Kritiškumą galima apibrèžti kaip nesutikimą su reiškiama pozicija pateikiant argumentus ir nurodant oponentų išsakytų teiginių klaidas arba trūkumų iškèlimą nagrinëjant nurodytus argumentus ar vertinimą arba tiesiog neigiamą vertinimą.

- Negatyvumas dažnai siejamas su skepsiu ir nesutikimu su tam tikrais teiginiais, juos neigiant ar jiems oponuojant, stengiantis pasipriešinti nurodymams ir siūlymams. Negatyvumas gali

Rengiant terminų aprašymus buvo remtasi „Tarptautinių žodžių žodynu“ (1985), "Cambridge Dictionary“ (https://dictionary.cambridge.org/dictionary/english/cynical), vocabulary.com (https://www.vocabulary.com/dictionary/cynicism), kitais. 
būti apibūdinamas kaip neigimas ar prieštaravimas, atmetimas, nepripažinimas.

- Skepticizmas apibūdinamas kaip nepasitikejjimas, nepatiklumas ir abejojimas. Politinès komunikacijos tyrèjai nurodo, kad skepticizmas yra apibrèžiamas kaip nepasitikejjimas politiniu procesu, tačiau tai nerodo paties politinio proceso neigimo.

- Cinizmas - žmogaus priklausomybès nuo visuomenès neigimas, normų ignoravimas, nepadorumas. Tačiau dažniausiai vartojama reikšmė - tyčiojimasis, grindžiamas nepasitikejjimo demonstravimu, netikejimu teiginiais ar asmenimis. Cinizmas dažnai aiškinamas ir kaip žmogaus prigimtinė savybè, polinkis negatyviai vertinti kitų kalbas, veiksmus, kartais abejonè bet kokių žmogaus veiksmų nesavanaudiškumu. Toks cinizmo interpretavimas yra itin ryškus politinejje komunikacijoje.

Kaip teigia mokslininkai, skepticizmas politinejje komunikacijoje dažnai vartojamas kaip cinizmo sinonimas, tačiau skepticizmas, skirtingai nuo cinizmo, turi ir teigiamą konotaciją: skepticizmas gali būti apibūdinamas kaip informacijos, kuri gaunama, patikrinimo procesas - abejonè, dažnai keliama kognityvinio disonanso, ir todèl jis pripažįstamas kaip pozityvus politinès komunikacijos reiškinys, o cinizmas daugiau siejamas su nepasitikejimu politikais ir politikos institucijomis, jų veiklos neigimu ir dèl to atsisakymu dalyvauti politiniuose procesuose (Fu, Mou, Miller, Jalette, 2011, p. 46, 56; Adriaansen, van Praag, de Vreese, 2010). Perfrazuojant Dano Jacksono (2010) pateiktą politinio cinizmo apibrèžimą, galima apibendrinti, kad politinis cinizmas yra pasitikejimo tiek vyriausybe, tiek politiniais procesais nebuvimas; negatyvumas ir rodomas nepritarimas politiniams lyderiams ar kandidatams i politinius ar valdžios postus. Reikia pasakyti, kad dažnai politinis cinizmas yra siejamas su kaltinimu, tiksliau, - tikejjimu ir teigimu, kad visa politinè sistema, o ypač esantys valdžioje, yra korumpuoti, ir todèl jais negalima pasitikèti.

Tokị teiginị sustiprina D. Jacksonas (2010, p. 78), tvirtindamas, kad yra du politinio cinizmo tipai: pirmasis, kuris vadinamas pro- 
bleminiu (angl. issue-specific), nurodo politikų su(si)siejimą su atitinkamomis problemomis, o antrasis, kuris vadinamas globaliuoju, - su politine sistema.

Politinis cinizmas yra suprantamas kaip kompleksinis reiškinys, apimantis ir palaikymo grupių ịtraukimą i politinę diskusiją, ir nesąžiningumą, ir siekị bet kokiomis priemonèmis lyderiauti, ir norą atrodyti gražiai, kelti baimę ir teigti, kad realiai nèra palikta žmogui jokio pasirinkimo, akcentuoti „didelių pinigų“ galią ir pan. (Jackson, 2010, p. 78). Verta paminèti ir tai, kad politinis cinizmas siejamas su politikų ir valdininkų etikos ir sąžiningumo vertinimu, tiksliau, teigimu apie jų nesąžiningus veiksmus (Dancey, 2012, p. 411), taip pat su piliečių neigiamomis nuostatomis, kritišku atitinkamų vyriausybès veiksmų vertinimu (Fu, Mou, Miller, Jalette, 2011, p. 46).

Politinis cinizmas, pasak politinès komunikacijos tyrèjų (Adriaansen, van Praag, de Vreese, 2010), yra pasitikejjimo ir tikejjimo nebuvimas ivvairiais politikos lygmenimis, negatyvumo ir nepritarimo politikams, politikos institucijoms ir jų veiksmams demonstravimas.

Politinis cinizmas yra tarsi skètinis terminas, apimantis kritiškumą, negatyvumą, populizmą, dabar itin ryškiai matomus politiniame, taip pat ir žiniasklaidos bei visuomenès diskursuose.

\section{Politinis cinizmas Lietuvoje: kokius politinio proceso aspektus ryškina politikai}

Stebint politinę komunikaciją žiniasklaidoje užsienyje ir Lietuvoje, matyti tam tikrų tendencijų panašumai, ypač jei politinė komunikacija žiniasklaidoje analizuojama aktyviuoju - kriziniu ar politinių rinkimų - laikotarpiu: būtent tuo metu atsiskleidžia populizmas, politinès komunikacijos pranešimų supaprastinimas arba „politikos supakavimas“ pasitelkiant ryšiu su visuomene specialistus, taip pat ryškus politinès komunikacijos veikejų negatyvumas vertinant politinę situaciją, vykstančius politinius procesus ar tiesiog oponentus. 
Lietuvoje, kaip ir užsienyje, „politinio cinizmo spirale“ yra ịtraukusi visus politinès komunikacijos veikejjus: politikus, žiniasklaidą ir visuomenę. Kaip pabrèžia Rasmusas Tue Pedersenas (2012, p. 225), žiniasklaida yra esminis informacijos šaltinis ir komunikacijos tarp politikų ir piliečių variklis. Pastaruoju metu naujienų žiniasklaida, pristatydama politinio gyvenimo ịvykius, ne tik konstruoja politinę piliečių dienotvarkę, iškelia tam tikras problemas ar pateikia jų vertinimus, bet ir įtvirtina atitinkamą komunikacijos stilių, kuriuo yra pristatomos politinès temos. Mokslininkų teigimu, „cinizmas neatsiranda vien dèl pateikiamo žiniasklaidos turinio, kad ir kaip būtų, jis atsiranda dèl politikų ir žurnalistų santykio“ (Brants, de Vreese, Möller, van Praag, 2009, p. 3), t. y. politikai perima žiniasklaidos pasiūlytą komunikacijos stilių ir taip įsitraukia $\mathfrak{i}$ "politinio cinizmo spiralę“, vèliau ị ją yra ịtraukiama ir visuomenè, ji perima žiniasklaidos ir politikų pasiūlytą komunikacijos toną.

Būtent žiniasklaidos vaidmuo didinant nepasitikejjimą politikais ir politikos institucijomis yra ryškinamas teigiant, kad dèl kintančio žiniasklaidos politinio turinio, kai tiriamosios žurnalistikos pagrindu parengtas naujienas keičia populiarus pramoginis turinys, dar kitaip anglų kalboje vadinamas „infotainment“ (lietuvių kalba galètų būti atitikmuo „idomiai pateikiama informacija“ ar „informacinė pramoga“) ar „soft-news“ (lengvosios ar pramoginès naujienos, „minkštosios“ naujienos), yra sustiprinamas neigiamas, kritiškas požiūris ị politikus, politikos institucijas, jų veiklą (Lengauer, Esser, Berganza, 2012). Tą patvirtina ir keletas panašių tyrimų (pvz., de Vreese, Elenbaas, 2008), atskleidžiančių tiesioginę sąsają tarp žiniasklaidoje pateikiamų naujienų pobūdžio ir politinio cinizmo, ir būtent šių politinès komunikacijos veikejjų sąveikos nulemtos atitinkamos elektorato elgsenos.

Žiniasklaida, būdama aktyvi politikos procesų dalyvè, ịsitraukia ị politinio cinizmo kūrimą ir plètrą, kita vertus, kaip jau minèta anksčiau šiame straipsnyje, $\mathfrak{i}$,cinizmo spiralę" yra ịtraukti ar ịsitraukę ir kiti politinio diskurso veikèjai, kas, viena vertus, gali rodyti žinias- 
klaidos galią siūlyti ir konstruoti politinę komunikaciją, jos toną, kita vertus, gali rodyti ir politikų prisitaikymą, ir žiniasklaidos diktuojamų „žaidimo taisyklių“ - pasiūlyto komunikacijos tono - perèmimą siekiant visuomenès informavimo priemonių dèmesio, palaikymo isitvirtinant žiniasklaidos kuriamame politiniame diskurse.

Šiame straipsnyje keliami keli tyrimo klausimai:

1) Ar Lietuvos politikai, užimantys valdžios institucijose postus, žiniasklaidos publikacijose taiko politinị cinizmą kaip priemonę? Klausimas keliamas siekiant nustatyti politinio cinizmo kaip politinès komunikacijos stiliaus taikymą politikų kalbose: norima išsiaiškinti, ar politinis cinizmas gali būti siejamas tik su oponavimu užimantiems valstybeje svarbius postus, ar tai yra politinès komunikacijos stilius, kuris taikomas nepriklausomai nuo užimamos pozicijos, dalyvavimo politiniuose procesuose intensyvumo.

2) Ar Lietuvos politikai, pasinaudodami žiniasklaida, pasitelkia politinį cinizmą kaip politinès komunikacijos stilių, ryškindami atitinkamas Lietuvos problemas? Klausimo formulavimas sietinas su vyraujančio politinio cinizmo tipo Lietuvoje nustatymu (remiantis Jacksonu, 2010).

Šiame straipsnyje bus analizuojami pačių politikų žiniasklaidai pateikti tekstai, kuriuose matyti politinio cinizmo raiška.

Tekstų analizei pasirinkta politinio cinizmo raiškos klasifikacija, sudaryta remiantis straipsnyje minètais politinio cinizmo bruožais:

- nepasitikejjimas valdžia, vyriausybe, politiniais procesais, atskirais politikais; kaltinimai politinės sistemos, politikų ir vyriausybès korumpuotumu;

- nepritarimas politiniams lyderiams ar kandidatams, jų išsakomiems teiginiams, keliamoms problemoms, pasitelkiant ir tariamą visuomenès nepritarimą;

- kaltinimas nesąžiningumu ir siekiu bet kokiomis priemonemis lyderiauti, politikų ir valdininkų etikos ir sąžiningumo neigiamas vertinimas. 
Analizei pasirinktas Delfi.lt naujienų portalas, jo skiltyje „Politikų akimis“ skelbti politikų pasirašyti tekstai nuo 2007 m. iki 2014 m. (tyrimui pasirinkus gegužès ir gruodžio mèn. 1-12 dienas). Pasirinktu laikotarpiu vyko keletas politinių rinkimų kampanijų: 2007, 2011 m. - rinkimai ị savivaldybių tarybas, 2008, 2012 m. - rinkimai $\mathfrak{i}$ Seimą, 2009 m. - i prezidentus.

Analizuotos 239 publikacijos (žr. 1 pav.), kurios pasirinktu laikotarpiu buvo spausdintos Delfi.lt portale kaip politikų parengti komentarai.

Publikacijų skaičiaus analizè atskleidžia politikų parengtų tekstų, publikuojamų žiniasklaidoje, nors ir nedidelį, bet tolygų daugejjimą (iki 2011-2012 m.) ir vèliau publikacijų skaičiaus nusistovejjimą. Toks publikacijų netolygus pasiskirstymas gali būti siejamas su politinių rinkimų periodu ir dèl to padidejusiu politikų siekiu pristatyti savo poziciją visuomenei pasitelkiant žiniasklaidos priemones.

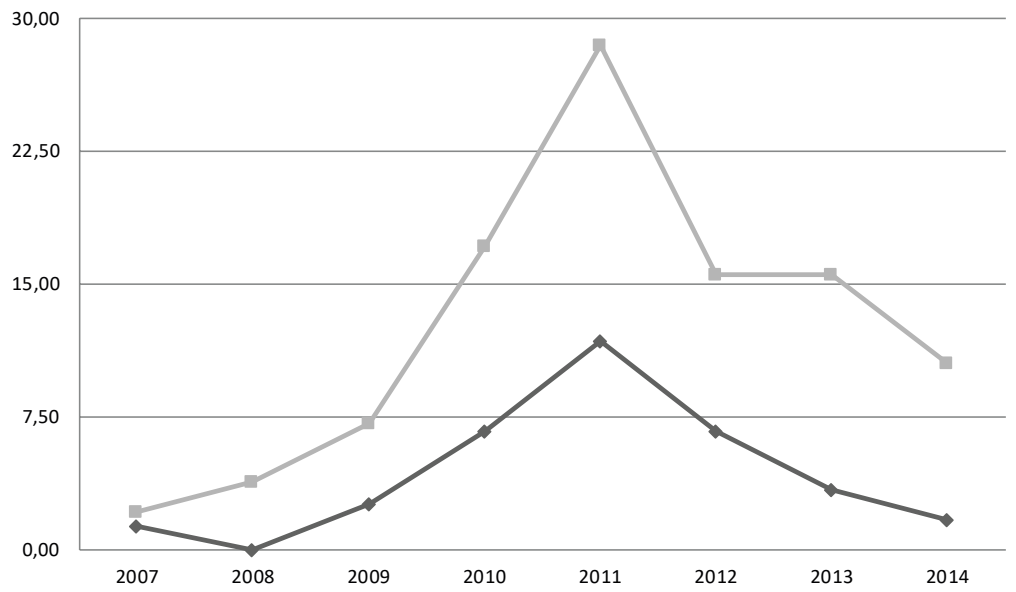

1 paveikslas. Publikacijų ir publikacijų, turinčių cinizmo požymių, skaičiai, procentais

Šviesiai pilka kreivè - bendras publikacijų skaičius, tamsi kreivè - publikacijų, turinčių cinizmo bruožų, skaičius. 
Analogiškas kitimas pastebimas ir vertinant cinizmo bruožų turinčių publikacijų, parengtų politikų, skaičiaus kaitą: iki $2011 \mathrm{~m}$. ryškus tokio pobūdžio publikacijų skaičiaus augimas, vèliau - publikacijų, turinčių cinizmo bruožų, skaičiaus mažejimas.

2011 m. ir 2012 m. išaugęs publikacijų skaičius, tarp jų ir turinčių cinizmo bruožų, gali būti siejamas ne su tuo metu vykusiais rinkimais (2011 m. vyko rinkimai ị savivaldybių tarybas, $2012 \mathrm{~m}$. - i Seimą), bet daugiau su politine situacija.

\section{Kritika, dominuojanti politikų tekstuose, kokia ji?}

Analizuojant politikų tekstus matyti kelių tipų kritika: kritikuojami politinių lyderių, politikų veiksmai, kalbos; kritikuojamos valdžios institucijos dèl neveikimo ar net žalingų valstybei veiksmų, jos kaltinamos korupcija (žr. 1 lentelę).

1. Politiku, ju kalbu ir veiklos kritika. Analizuojant politikų tekstus, paskelbtus žiniasklaidoje, matyti, kad opozicijoje esantys politikai, pristatydami tam tikrą problemą, dažnai ryškina atitinkamo politiko (prezidento ar vyriausybès vadovo) veiksmus, nurodydami jų klaidas, netinkamą reakciją i problemą ar nekompetenciją: „<...> prezidentas Valdas Adamkus vis rasdavo progą papriekaištauti dabartiniams valstybėms vadovams esq šie "per vienq naktį“ sugriové Lietuvos santykius su Lenkija, kurie <...> jo isitikinimu, buve „auksiniai“(A. Čaplikas, 201105 03); „Jos ekscelencija labai audringai reagavo ị opozicijos siūlymus <...>“" (A. Valinskas, 201012 06)

Dažnai politikų veiksmų vertinimas pristatomas pasitelkiant palyginimus ar tiesiog pasišaipant: „bet koks triukšmavimas tik primena vištą, kuri padejjusi viso labo tik kiaušini, kudakuoja, kad pagimdè asteroidą. <...> Galutinis sprendimas priklauso nuo vieno žmogaus. Deja, Vyriausybė tokio stipraus vadovo <...> neturi.“ (A. Butkevičius, 201005 11)

Vertindami politinių oponentų veiksmus, politikai tekstuose ryškina abejones jų veiksmais, supriešindami juos su ankstesnemis 
politikų kalbomis, nurodydami prieštaravimus ar neatitikimus tarp to, kas pasakyta ir kas daroma, pavyzdžiui: „Klausimas [R. Juknevičienei - R. M. pastaba] galètų būti toks: „Kodèl Jūs taip nemylèjote Lietuvos kariuomenès, kad neskyrète jai reikalingo finansavimo?“ (K. Krisčiūnas, 201405 09); „Patikèjau, kad daugiau nebegrišime prie mokesčių didinimo klausimo. Tačiau kas vyksta dabar? Dar viena naktinè reforma.“ (A. Čaplikas, 2011 12 08)

Politikų tekstuose neigiamai vertinami ir atitinkami valdžios veiksmai, ne tik pateikiant kritiką, bet ir išryškinant politikos procesų neskaidrumą, politikų nekompetenciją (pvz., „<...> sukeltas ažiotažas ir net isterija akivaizdžiai parodé, jog ne pats vizitas buvo esmé, o kad važiavo ne tie <...> (G. Kirkilas, 201312 02)

2. Nepasitikejimas valdžios institucijomis ir ju veikla. Vienas iš dažniausiai pasitaikančių cinizmo bruožų politikų tekstuose - tai valdžios institucijų veiklos kritika, ryškinant veiklos trūkumus ar atskleidžiant vyriausybès neveiksnumą: „iš tiesų esminis pasibaigiančios valdžios metų simbolis yra tai, kad, nepaisant visų propagandistinių pastangų, valdžios nuveiktų darbų sąrašas yra labai skurdus“ (A. Kubilius, 201312 12); „ką veikè valdantieji visus trejus metus <...> (M. Bastys, 2011 12 09); „tebesimégaudamas prabėgusių metų rinkimų pergalès svaiguliu, premjeras pamėgo kartoti melagingus teiginius apie valdančiosios koalicijos nuopelnus ir milžinišką indèlị“. (D. Kreivys, 2013 12 06)

Nepasitikejimas sietinas ir su politinių oponentų kaltinimu populizmu, visuomenei teikiamais neigyvendinamais pažadais: „Veidmainystė yra politinių intrigų dalis.“ (M. A. Pavilionienė, 200912 06); „<..> Svarbiausia - maitinti tautą pažadais. Tiksliau - parduoti juos su pilietiškumo etikete už labai gerus pinigus.“ (R. Palaitis, 201205 03)

3. Politikų kaltinimai valdžios atstovams, politiniams oponentams korumpuotumu ir daroma žala valstybei. Vienas iš pagrindinių cinizmo bruožų greta deklaruojamos išsakomos kritikos politikų veiksmams, reiškiamo nepasitikejjimo yra pateikiami kaltinimai politikams korupcija. Tokie kaltinimai teikiami ir politikų publikuoja- 
muose tekstuose: „Jei kyšių „apyvarta“ ir sumažèjo, tai pats mąstymas apie korupciją iš esmès nesikeičia nei žiemą, nei vasarą. <...> Galima sakyti, jog Lietuvoje net statome paminklus korupcijai.“ (A. Bulotaitè, 201312 09); „Galima spèti, kad tokių projektų igyvendinime jų proteguotojams visuomet kas nors „nubyra“““ (M. Adomènas, 201305 08)

Politikų kalbose nevengiama ir abstrakčios politinių oponentų veiksmų kritikos, tiesiog pateikiant kaltinimus dẻl daromos žalos valstybei, jos naikinimo ir pan.: „Visos iki vienos Lietuvos Respublikos vyriausybès gali varžytis tik vienu aspektu - kiek kuri padarè žalos tautos kultūrai <...>“ (Š. Navickas, 201105 10); „Vis dažniau tenka ìsitikinti, jog iš buvimo Europos Sąjungoje Lietuvai yra daugiau žalos nei naudos, o pataikaujant Briuselio biurokratams, nacionaliné valstybė vis dažniau tampa nepatogiu kliuviniu.“ (V. Valkiūnas, 201205 09).

Apibendrinant analizei pasirinktus tekstus buvo pastebètas negatyvumo pasireiškimas: politikų tekstuose ne tik pateikiama kritika, nesutinkant su oponentų veiksmais, bet ir prieštaravimas ar tiesiog atmetimas tam tikrų veiksmų, neigiamas jų galimos naudos, o dažnai - priešingai, teigimas apie daromą žalą, kenkimą. Pateiktose publikacijose, kurios buvo priskirtos prie turinčių cinizmo bruožų, pastebèta ir skepticizmo apraiškų, t. y. pateikiamos abejonės dèl valdžios institucijų priimamų sprendimų ir sprendimų prièmimo proceso efektyvumo, veiklos pagrịstumo. Verta pabrèžti ir tai, kad tirtose politikų publikacijose matyti ir ciniškas požiūris ị atitinkamus politikus, jų kalbas, veiksmus, ne tik pateikiant neigiamą vertinimą, bet ir kaltinant savanaudiškumu, nesąžiningumu.

\section{Išvados}

Lietuvos politikų žiniasklaidoje publikuojamuose tekstuose matyti negatyvumo, skeptiškumo, kritikos ir cinizmo pasitelkimas. Politinès komunikacijos tyrèjai nurodo esminius cinizmo bruožų raiškos atvejus, kurie buvo nustatyti ir analizuojant politikų tekstus Lietuvos 
žiniasklaidoje: tai nepasitikejjimas valdžia, vyriausybe, politiniais procesais, atskirais politikais; kaltinimai politinès sistemos, politikų ir vyriausybės korumpuotumu; nepritarimas politiniams lyderiams, ju keliamoms problemoms, pasitelkiant ir tariamą visuomenės nepritarimą; kaltinimas nesąžiningumu ir siekiu bet kokiomis priemonėmis.

Nors cinizmas nèra dominuojantis politinès komunikacijos Lietuvoje bruožas, bent jau tai nebuvo nustatyta tiriant politikų tekstus, publikuojamus žiniasklaidoje, nustatyta, kad politikai, siekdami išsakyti savo nepritarimą valdžios institucijų ar jų vadovų veiksmams, oponavimui konkurentams politikoje, pasitelkia cinizmą kaip politinès komunikacijos priemonę. Nors užsienio tyrẻjai, analizuodami politinị cinizmą, pabrěžia politikų tekstuose dominuojantị etikos pažeidimų (tiksliau, neetiškos veiklos) ir nesąžiningumo akcentavimą, šitaip atskleidžiant politikų siekị ne visuomet sąžiningai siekti tikslų, tirtose ir šiame straipsnyje analizuotose publikacijose yra ir kaltinimų korupcija bei nesąžiningumu siekiant naudos.

Kaip buvo minèta, užsienio mokslininkai išskiria politinio cinizmo tipus, nurodydami, kad kritiškumas gali būti susietas su politinių procesų neigimu apskritai arba su kritika, išsakoma dèl konkrečių politikų veiksmų, atliekamų sprendžiant atitinkamas problemas. Analizuojant Lietuvos politikų tekstus, publikuotus žiniasklaidoje, pastebėti gana bendro pobūdžio kaltinimai, išsakomi arba konkrečiam politikui, arba apskritai vyriausybei, neakcentuojant vienos konkrečios problemos. Tokią nuomonę sustiprina ir tai, kad politikų tekstuose, kuriuose pastebèta cinizmo bruožų, yra aptariamos ne politikos, ekonomikos ar socialinès problemos, o dažniau analizuojamas ir kritiškai, negatyviai vertinamas visas politinių sprendimų prièmimo procesas.

Galima teigti, kad Lietuvos politikų tekstuose, publikuotuose žiniasklaidoje, politinis cinizmas išryškèja per pristatomą nepasitikejimą vyriausybe, politiniais procesais; nepritarimą politiniams lyderiams, jų veiksmams. Pabrèžtina ir tai, kad politinis cinizmas 
tekstuose atsispindi ir per teigiamus ar politikų išsakomus kaltinimus, kad vyriausybé, atsakingi politinio proceso veikejjai yra korumpuoti, jais negalima pasitikèti.

Aptariant Lietuvos ir užsienio politinio cinizmo raišką politinejje komunikacijoje, verta akcentuoti, kad tiriant Lietuvos žiniasklaidoje skelbiamus politikų tekstus nèra pastebèta radikaliam politiniam cinizmui būdingų bruožų, tokių kaip baimès kèlimas, siekiant išryškinti žmogaus bejëgiškumą, apribotą jo laisvę rinktis, „didžiųjų pinigų“ galią.

Dar vienas aspektas, išryškejjęs tyrimo metu, - politikų kalbose, kuriose pastebėta cinizmo bruožų, buvo reiškiama pabrèžtinai asmeninè politiko, o ne jo atstovaujamos politinès partijos ar kitos politikos institucijos nuomonè. Taigi galima manyti, kad politikai jaučia atsakomybę viešai pateikdami vertinimus politikos institucijos vardu ir kritiką ar negatyvius vertinimus yra labiau linkę išsakyti kaip asmeninę nuomonę.

Politinio cinizmo bruožų tyrimas politinejje komunikacijoje Lietuvos žiniasklaidoje leidžia manyti, kad cinizmas politikų kalbose pasitelkiamas tik kaip komunikacijos stilius, galintis atkreipti žiniasklaidos ar visuomenès dėmesi ị politiko keliamas problemas, išsakomus argumentus.

\section{Literatūra}

Adriaansen, M. L.; van Praag, P.; de Vreese, C. H. (2010) Substance Matters: How News Content can Reduce Political Cynicism. International Journal of Public Opinion Research , 22 (4), 433-457.

Brants, K.; de Vreese, C.; Möller, J.; van Praag, P. (2009). The Real Spiral of Cynicism? Symbiosis and Mistrust between Politicians and Journalists. International Journal of Press/Politics, 1-16.

Van Dalen, A.; Albæk, E.; de Vreese, C. (2011) Suspicious minds: Explaining political cynicism among political journalists in Europe. European Journal of Communication. Vol. 26, Issue 2, 147-162. 
Dancey, L. (2012) The Consequences of Political Cynicism: How Cynicism Shapes Citizens' Reactions to Political Scandals. Political Behavior, 34, 411-423.

Elenbaas, M.; de Vreese, C. H. (2008) The Effects of Strategic News on Political Cynicism and Vote Choice Among Young Voters. Journal of Communication, 58, 550-567.

Fu, H.; Mou, Y.; Miller, M. J.; Jalette, G. (2011, Summer) Reconsidering political cynicism and political involvement: A test of antecedents. American Communication Journal, 13(2), 44-61.

Guggenheim, L.; Kwak, N.; Campbell, S. W. (2011) Nontraditional News Negativity: The Relationship of Entertaining Political News Use to Political Cynicism and Mistrust. International Journal of Public Opinion Research, 23 (3), 287-314.

Jackson, D. (2010) Strategic Media, Cynical Public? Examining the Contingent Effects of Strategic News Frames on Political Cynicism in the United Kingdom. International Journal of Press/Politics, 16(1), 75-101.

Lengauer, G.; Esser, F.; Berganza, R. (2012) Negativity in political news: A review of concepts, operationalizations and key findings. Journalism 2012 13: 179 Prieiga internete: <http://jou.sagepub.com/ content/13/2/179.refs.html>

Levi, M.; Stoker, L. (2000) Political trust and trustworthiness. Annual Review of Political Science, 3, 475-507.

Pedersen, R. T. (2012) The game frame and political efficacy: Beyond the spiral of cynicism. European Journal of Communication, 27(3), 225-240.

Pels, D. (2003) Aesthetic Representation and Political Style. Rebalancing Identity and Difference in Media Democracy. In D. P. John Corner (Ed.), Media and the Restyling of Politics (pp. 41-66). SAGE Publications. 
1 lentelè. Politinio cinizmo bruožai ir ištraukos iš politikų tekstų, publikuotų žiniasklaidoje ir turinčių cinizmo bruožų

\begin{tabular}{|c|c|}
\hline $\begin{array}{c}\text { Politinio cinizmo } \\
\text { bruožai }\end{array}$ & Politikų tekstų ištraukos \\
\hline $\begin{array}{l}\text { Politinių lyderių } \\
\text { veiksmų kritika }\end{array}$ & 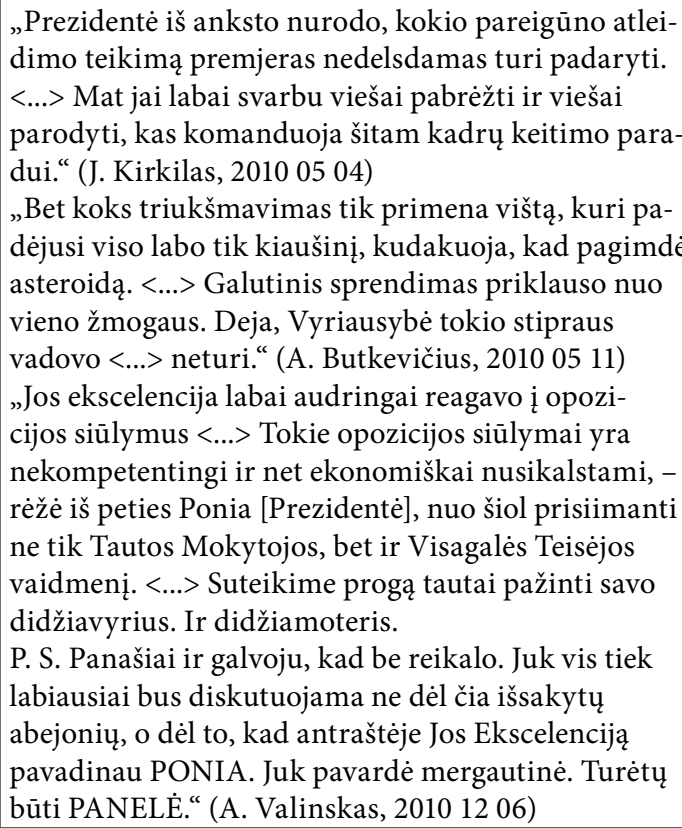 \\
\hline $\begin{array}{l}\text { Politikos institucijų } \\
\text { veiklos kritika }\end{array}$ & 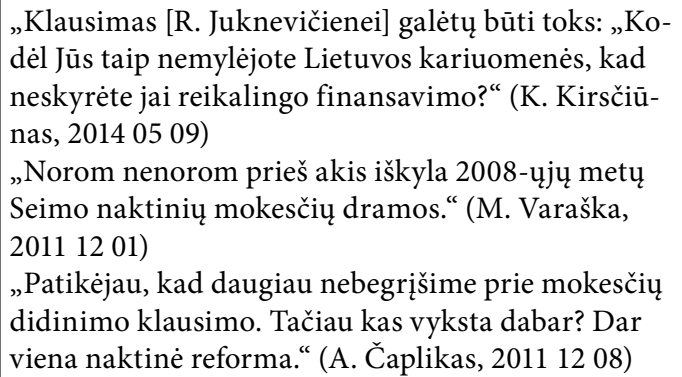 \\
\hline
\end{tabular}




\begin{tabular}{|c|c|}
\hline $\begin{array}{c}\text { Politinio cinizmo } \\
\text { bruožai }\end{array}$ & Politikų tekstų ištraukos \\
\hline Oponentų kritika & $\begin{array}{l}\text { „<...> sukeltas ažiotažas ir net isterija akivaizdžiai } \\
\text { parode, jog ne pats vizitas buvo esmė, o kad važiavo } \\
\text { ne tie <...>“ (G. Kirkilas, } 201312 \text { 02) } \\
\text { „Konservatoriai patys sau išpranašavo ir išaugino } \\
\text { šias negandas, už kurias, deja, turès moketi Lietuvos } \\
\text { žmonès.“ (A. Sysas, } 201212 \text { 03) } \\
\text { „Mes <...> žiūrim i̇ procesus Lietuvoje realistiškai, } \\
\text { deja, konservatorių kalbos nuo darbų smarkiai } \\
\text { skiriasi, o pastarieji optimizmu tikrai nekvepia.“ } \\
\text { (A. Butkevičius, } 20101208 \text { ) }\end{array}$ \\
\hline $\begin{array}{l}\text { Kritika dèl politikų } \\
\text { neveikimo }\end{array}$ & $\begin{array}{l}\text { "Iš tiesų esminis pasibaigiančios valdžios metų sim- } \\
\text { bolis yra tai, kad, nepaisant visų propagandistinių } \\
\text { pastangų, valdžios nuveiktų darbų sąrašas yra labai } \\
\text { skurdus.“ (A. Kubilius, } 201312 \text { 12) } \\
\text { "Rinkimǔ kampanijos pažadas „mes žinome kaip“ } \\
\text { akivaizdžiai tapo „neturime kas“. Populizmas priejo } \\
\text { liepto galą." (V. Stundys, } 201212 \text { 10) } \\
\text { „Ką veikė valdantieji visus trejus metus <....“" } \\
\text { (M. Bastys, 2011 12 09) }\end{array}$ \\
\hline $\begin{array}{l}\text { Nepasitikejjimas } \\
\text { valdžios, politikos } \\
\text { institucijomis }\end{array}$ & $\begin{array}{l}\text { „Šaukim, rekim „už teisingumą", bet nedarykim } \\
\text { nieko, kad teisingumas ịvyktų. Svarbiausia - maitinti } \\
\text { tautą pažadais. Tiksliau - parduoti juos su pilietišku- } \\
\text { mo etikete už labai gerus pinigus.“ (R. Palaitis, } 2012 \\
0503 \text { ) } \\
\text { „Veidmainystė yra politinių intrigų dalis.“ (M. A. Pa- } \\
\text { vilionienè, 2009 12 06) }\end{array}$ \\
\hline $\begin{array}{l}\text { Kaltinimai sakant } \\
\text { netiesą }\end{array}$ & 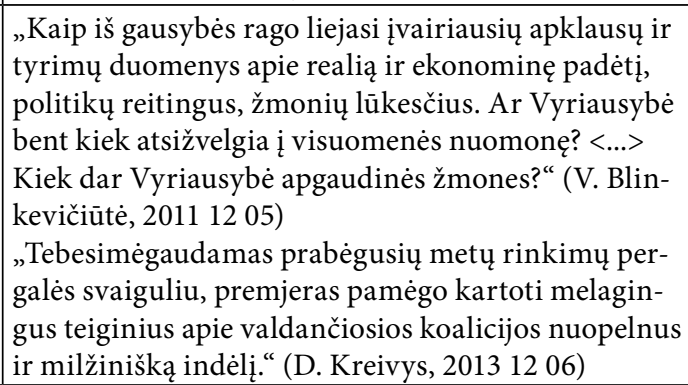 \\
\hline
\end{tabular}




\begin{tabular}{|c|c|}
\hline $\begin{array}{c}\text { Politinio cinizmo } \\
\text { bruožai }\end{array}$ & Politikų tekstų ištraukos \\
\hline $\begin{array}{l}\text { Kaltinimai korum- } \\
\text { puotumu }\end{array}$ & 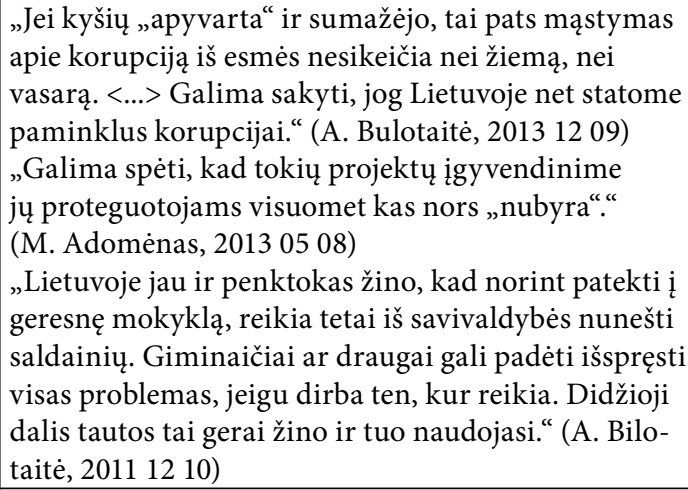 \\
\hline $\begin{array}{l}\text { Kaltinimai darant } \\
\text { žalą valstybei }\end{array}$ & $\begin{array}{l}\text { „I paraštes išstumiama tai, kas leidžia mums išlikti } \\
\text { tauta, Valstybe, o ne tiesiog gyvenama teritorija.“ } \\
\text { (G. Labanauskas, } 201305 \text { 12) } \\
\text { „Vis dažniau tenka îsitikinti, jog iš buvimo Europos } \\
\text { Sąjungoje Lietuvai yra daugiau žalos nei naudos, o } \\
\text { pataikaujant Briuselio biurokratams, nacionalinè } \\
\text { valstybė vis dažniau tampa nepatogiu kliuviniu.“ } \\
\text { (V. Valkiūnas, } 20120509 \text { ) } \\
\text { „Visos iki vienos Lietuvos Respublikos vyriausybès } \\
\text { gali varžytis tik vienu aspektu - kiek kuri padarè } \\
\text { žalos tautos kultūrai ir genofondui.“ (Š. Navickas, } \\
\text { 2011 05 10) } \\
\text { "Maždaug } 2012 \text { m. gruodžio } 21 \text { d. Lietuvoje iš tiesų } \\
\text { gali ịvykti „pasaulio pabaiga“, nes jos viešajame } \\
\text { gyvenime oficialiai, iškilmingai ir atvirai bus } \\
\text { palaidotas bet koks, dar kur nors likęs padorumas.“ } \\
\text { (G. Songaila, 2012 12 10) }\end{array}$ \\
\hline
\end{tabular}




\title{
INTERACTIONS OF POLITICIANS AND MEDIA: CYNICISM AS POLITICAL COMMUNICATION STYLE
}

\author{
Renata MatkeviČIEnĖ
}

\section{Summary}

Keywords: politicians; media; political communication; cynicism; criticism; negativity; political communication style.

The choice of the topic has been inspired by the recent tendency to critically evaluate political processes both in society and in the media discourse: a negative, critical approach, expressed by media representatives, political actors and political commentators, public figures, and the public, is noticeable when analyzing political processes, actions of government or peculiar politicians.

Negativity is noticeable in the discourse of politicians' communication when political actors comments actions or speeches of opponents, the problems raised by the opponents are often commented critically, expressing only a negative opinion, indicating only negative arguments or critical remarks. Of course, this kind of negative evaluation of actors of policy-making process is mainly taken over by the media, as citizens do not actively participate in political processes and see political processes and interactions of politicians only in and from media. Media's discourse is a place where political communication style is highlighted: media is a medium for politicians and it 's only a reflection of politics in the media, but largely based on the content that the media is constructing the public opinion about politics, politicians, political institutions and their activities is shaped. Political discourse in media is constructed not only by media (it's clear that media is a biased constructor of political field), but it is also clear that without active participation of politicians in media discourse it would be hard to construct political content for media, - so political communication in the media discourse is the result of interactions between politicians and the media, in both content and style of communication.

This article will analyze cynicism as a style of political communication and its expression in the media by exploring the content of the statements of politicians in the media. In the article qualitative analysis of the content of several years of articles by Delfi.lt in the column "Politicians' eyes" is presented, highlighting elements of political cynicism in comments presented by political actors.

Iteikta 2016 m. liepos $19 d$. 